\title{
Shaken, Not Stirred - A Percussion Scarification Technique
}

\section{NABIL Y KHADDURI AND JOHN T HARRINGTON}

\section{A B STRACT}

A pneumatic paint shaker was used to break seed dormancy in 2 reclamation species: New Mexico locust (Robinia neomexicana Gray [Fabaceae]) and black locust (Robinia pseudoacacia L.

[Fabaceae]). This percussion treatment improves germination over hot water, sulfuric acid, or mechanical scarification methods because it acts directly on the strophiole - the natural site of water entry to the seed. Consequently, percussion scarification is more likely to produce undamaged seeds and healthy seedlings. This low-cost percussion system holds promise for successfully pretreating seeds from a range of species of the ecologically important Papilionoideae subfamily of the Fabaceae family.

KEY WORDS: dormancy, strophiole, New Mexico locust, black locust

NOMENCLATURE: ITIS (2001)

S eeds can exhibit a wide range of dormancy mechanisms that in nature influence timing of germination and in nurseries present obstacles to propagation. Seeds of the Papilionoideae subfamily of the Fabaceae (bean) family often exhibit physical dormancy, where a thick seed coat prevents movement of water to the embryo. Members of the Papilionoideae subfamily used in reclamation include Robinia L., Melilotus P. Mill., Trifolium L., and Astragalus L. genera. Overcoming seed dormancy in these species requires loosening of the strophiole, a swelling of the seed coat close to the stalk scar (Kelly and van Staden 1987). Once loosened, water can enter the seed and germination can proceed.
Traditionally, scarification treatments utilizing boiling water, sulfuric acid, or abrasive surfaces have been used to break dormancy in these species. However, such treatments can indiscriminately degrade the seed coat, resulting in damaged seeds and unhealthy germinants (Hine and others 1997). Based on a methodology known as percussion scarification (Hamly 1932), we have improved a technique to effectively overcome physical dormancy in 2 reclamation species: New Mexico locust (Robinia neomexicana Gray [Fabaceae]) and black locust (Robinia pseudoacacia L. [Fabaceae]) (Khadduri and others forthcoming). This technique increases germination by loosening cells of the strophiole while minimizing damage to the seed coat.

A simple, low-cost (less than US\$ 150) percussion system can be made using a pneumatic paint shaker (Central Pneumatic, model \#00422, Camarillo, California) (Figure 1). Adjusting the compressed air pressure, one can regulate the frequency of oscillation. In this system, air pressure is maintained at 80 psi \pm 5 psi, resulting in approximately 350 oscillations per minute (Khadduri and others 2002). For small seed lots, seeds are placed in a 4-oz soil tin (US Can, Lobard, Illinois) and the lid is secured with duct tape. To take advantage of greatest lateral movement of the paint shaker, a spacer (paint can) is used to position the soil tin at the end of the shaking arm (Figure 2). This allows shaking to occur at the greatest distance from the pivot point or fulcrum. Tins are placed perpendicular to the direction of shaking motion, allowing seeds to impact at greatest force by hitting flat surfaces of the soil tin. Following treat-

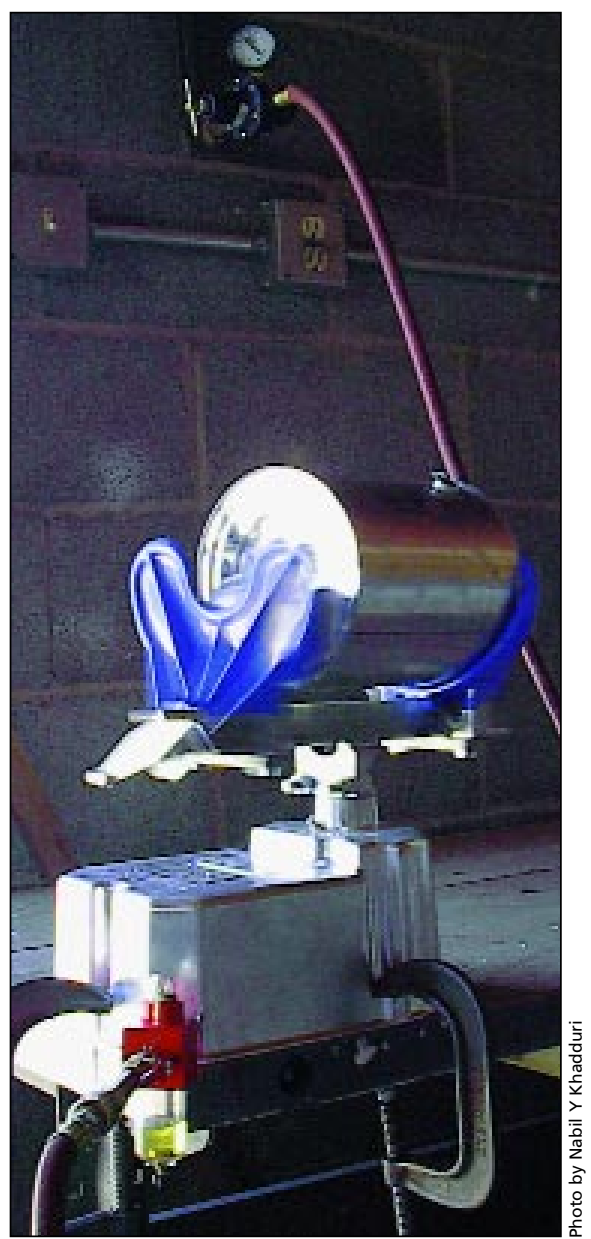

Figure 1 - Pneumatic paint shaker.

ment, seeds are soaked in water for $24 \mathrm{~h}$ before sowing.

Four minutes of percussion maximized germination for both New Mexico locust and black locust. Durations as short as $2 \mathrm{~min}$ of percussion significantly increased germination over a standard hot water treatment for both species. Seeds percussed for up to 4 min have consistently resulted in healthy seedlings (Khadduri and others 2002). For large-scale production, growers may 


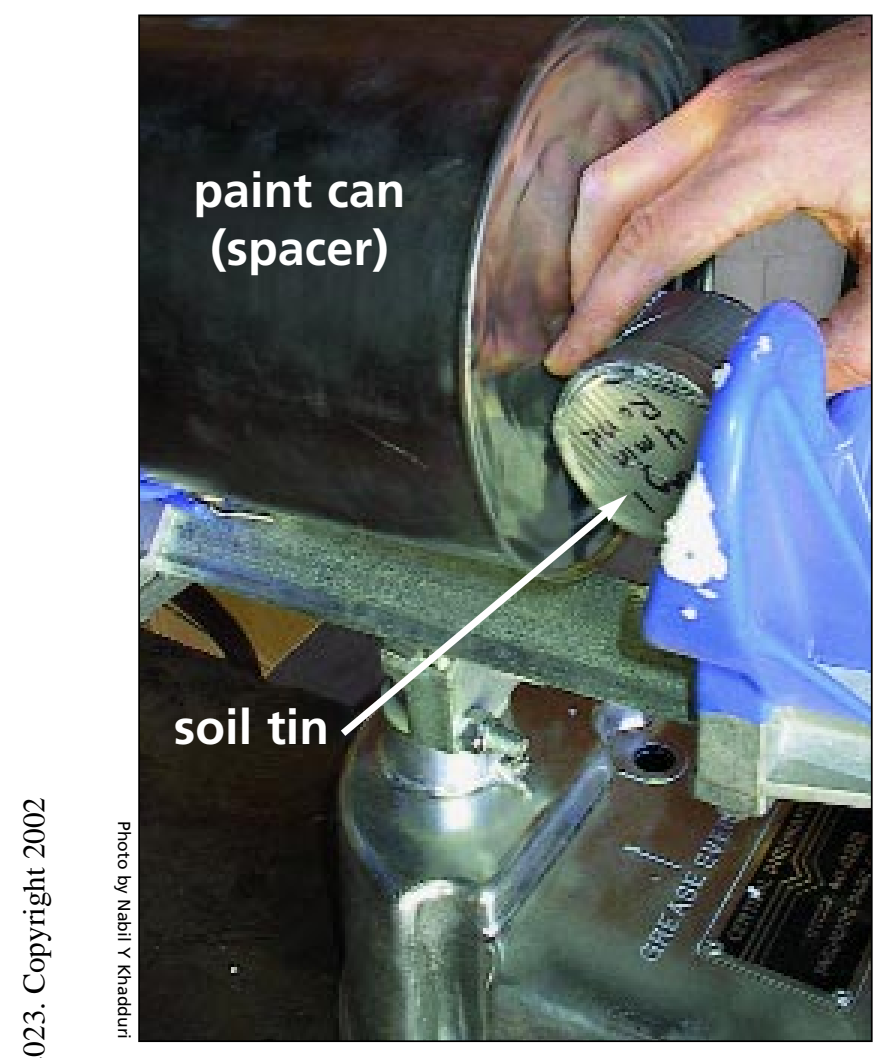

Figure 2 - Placing soil tin containing seeds at end of shaker arm. wish to experiment with larger quantities of seeds and larger-sized soil tins.

\section{ACKNOWLEDGMENTS}

This research was funded, in part, by the New Mexico Agricultural Experiment Station McIntire-Stennis Grant No. 01527052 and grant funding from Molycorp Inc, Questa,

New Mexico.

\section{REFERENCES}

Hamly DH. 1932. Softening of the seeds of Melilotus alba.

Botanical Gazette 93:345-375.

Hine S, Harrington JT, Dreesen DR. 1997. Seed scarification requirements for Robinia neomexicana. In: Harrington JT, technical coordinator. Proceedings, Third Southwestern Container Growers Conference; 1997 Feb 12-13; Fort Collins, Colorado. Mora (NM): New Mexico State University, Mora Research Center.
[ITIS] Integrated Taxonomic Information System. 2001. Biological names. Version 4.0 [Online].

URL: http://www.itis.usda.gov (accessed 14 Feb 2002).

Kelly KM, van Staden J. 1987. The lens as the site of permeability in the papilionoid seed

Aspalathus linearis. Journal of Plant Physiology 128(4/5):395-404.

Khadduri NY, Harrington JT, Rosner LS, Dreesen DR. 2002. Percussion as an alternative scarification for New Mexico locust and black locust seeds. In: Dumroese RK, Riley LE, Landis TD technical coordinators. National proceedings: forest and conservation nursery associations1999, 2000, and 2001. Ogden (UT): USDA

Forest Service, Rocky Mountain Research Station. Proceedings RMRS-P. Forthcoming.

\section{AUTHOR INFORMATION}

Nabil Y Khadduri

Graduate Research Assistant nkhadduri@hotmail.com

John T Harrington

Associate Professor

joharrin@nmsu.edu

New Mexico State University Mora Research Center Mora, NM 87332

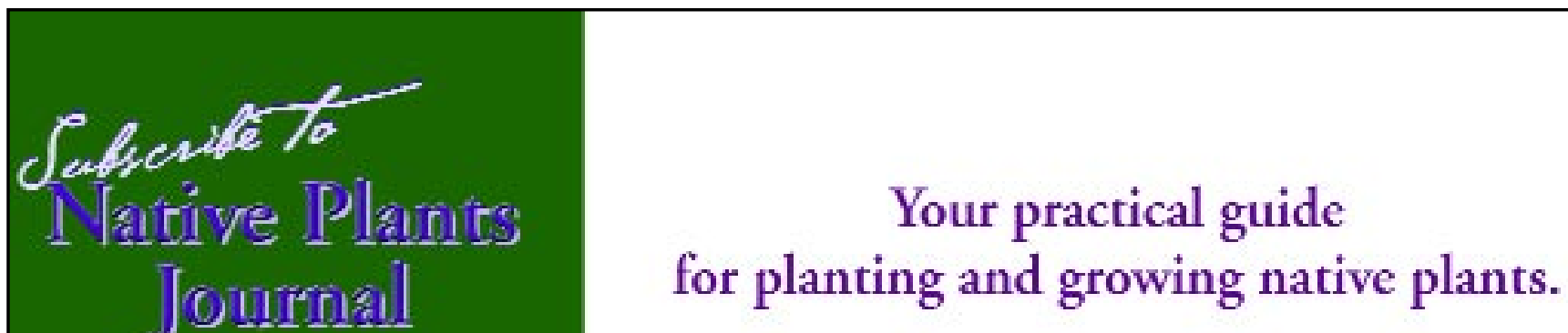

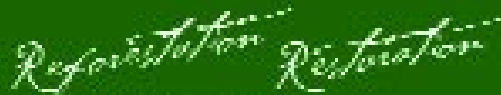

gursedicaping

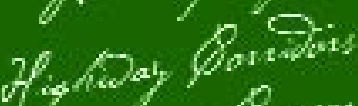

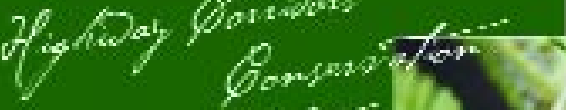

Reforistar

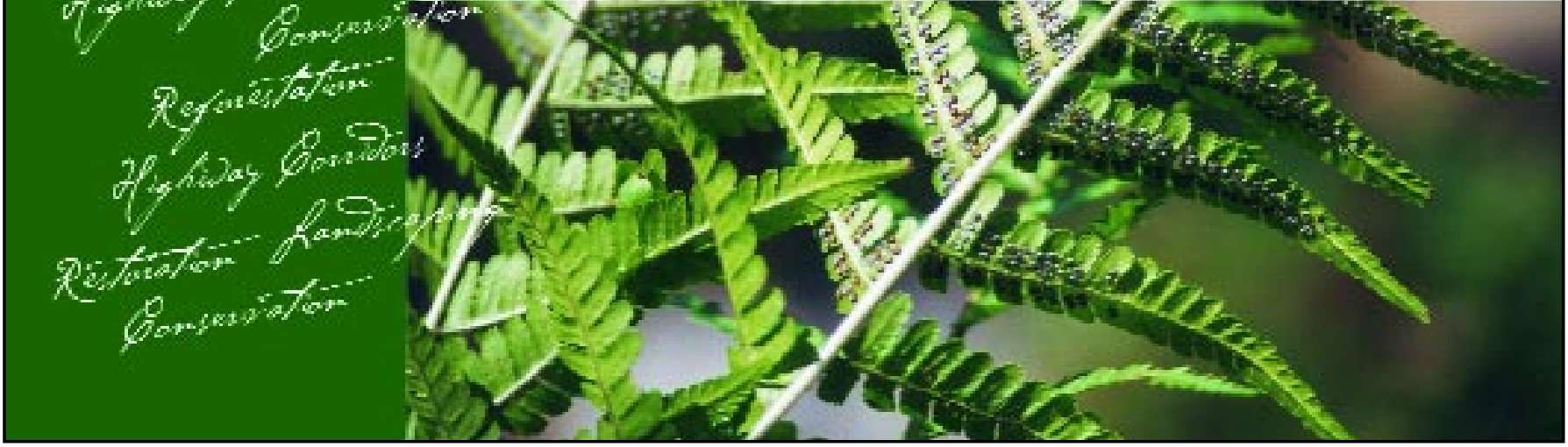

